\title{
RASIONALITAS DAN ADAPTASI SOSIAL (STUDI KASUS PENDUDUK MIGRAN DI PERDESAAN MADURA)
}

\author{
Hoiril Sabariman', Fidela Dzatadini Wahyudi², Amrullah ${ }^{3}$, Siti \\ Halimatus Sadiyah ${ }^{4}$, Mochamad Fawas Ramadhan ${ }^{5}$
}

\begin{abstract}
The migration of people to settle in a region often causes conflict. Conflict is caused by several factors such as differences in customs, economic, political, and educational disparities of the home region and the current community environment. Qualitative research with this case study approach is intended to analyze the rationality of the residents choosing Fusha Village and the social adaptation strategies carried out by the migrant population in the community. collected from migrant communities, community leaders, and village governments. Observations, in-depth interviews, and several related documents are analyzed with rationality theory. The results showed that the migrant population chose Fusha Village because of the environment of the community that is more accepting of diversity, the availability of health facilities, education, economy (market). Strategies carried out by migrant communities, first; language adaptation, as most of the migrant population is from Java. Second, socio-cultural adaptation, the migrant population participates in various citizen activities such as tahlilan (Religious in Islam), marriage, and several other activities. Third; food adaptation is tailored to the tastes of the local community. Fourth; cross-marriage between the migrant population and the local community. The scientific contribution of this article is to add to the understanding that in addition to factors close to the city, the complete facilities of militated migrant populations choosing to the house are security, comfort, and harmony in society.
\end{abstract}

Keywords: Rationality, Adaptation, Migration

\begin{abstract}
Abstrak
Migrasi penduduk untuk menetap di suatu wilayah sering menimbulkan konflik. Konflik disebabkan karena beberapa faktor antara lain perbedaan adat istiadat, kesenjangan ekonomi, politik dan pendidikan daerah asal dengan lingkungan masyarakat saat ini. Penelitian kualitatif dengan pendekatan studi kasus ini pertujuan menganalisis rasionalitas penduduk memilih Desa Fusha dan strategi adaptasi sosial yang dilakukan oleh penduduk migran di lingkungan masyarakat. primer dikumpulkan dari masyarakat migran, tokoh masyarakat dan pemerintah desa. Hasil observasi,

\footnotetext{
${ }^{1}$ Magister Ilmu Sosial, Universitas Brawijaya, Malang, Indonesia

2,3,4,5 Sosiologi Pembangunan, Magister Ilmu Sosial, Universitas Brawijaya, Malang, Indonesia

${ }^{1}$ hoirilsabariman@yahoo.com
} 
in-depth interview, dan beberapa dokumen terkait dianalisis dengan teori rasionalitas. Hasil penelitian menunjukkan penduduk migran memilih Desa Fusha karena lingkungan masyarakat yang lebih menerima keberagaman, tersedianya fasilitas kesehatan, pendidikan, perekonomian (pasar). Strategi yang dilakukan oleh masyarakat migran, pertama; adaptasi bahasa, karena sebagian besar penduduk migran berasal dari Jawa. Kedua, adaptasi sosial kultural, penduduk migran mengikuti berbagai kegiatan warga seperti tahlilan, pernikahan dan beberapa kegiatan lainnya. Ketiga; adaptasi makanan disesuaikan dengan selera masyarakat lokal. Keempat; melakukan pernikahan silang antara penduduk migran dan masyarakat lokal. Kontribusi keilmuan artikel ini adalah menambah pemahaman bahwa selain faktor dekat dengan kota, fasilitas yang lengkap salah faktor penduduk migran memilih tempat tinggal adalah keamanan, kenyamanan dan keharmonisan dalam masyarakat.

\section{Kata kunci : Rasionalitas, Adaptasi, Migrasi}

\section{PENDAHULUAN}

Dewasa ini pembahasan seputar migrasi penduduk menarik untuk didiskusikan secara ilmiah. Pembahasan menarik dari fenomena migrasi penduduk dapat dilihat dari berbagai aspek, mulai dari pemerintah dalam penentu kebijakan, aspek sosial, politik, ekonomi, hukum, keagamaan, kultur, maupun dari perspektif yang lain. Saat melakukan migrasi, penduduk memiliki keinginan untuk kehidupan lebih baik, sehingga migrasi merupakan salah satu tujuan penduduk meninggalkan tanah dan keluarga untuk bekerja di daerah lain. Proses migrasi yang dilakukan masyarakat dengan latar belakang yang berbeda-beda akan berpengaruh terhadap tatanan dan keteraturan sosial budaya yang sudah ada, terutama bagi masyarakat lokal tuan rumah (host population) (Nasution, 2018: 150).

Seperti contoh, di tempat tujuan kebiasaan-kebiasaan yang dibawa dari daerah asal oleh penduduk migran akan mengalami perubahan termasuk orientasi terhadap kampung halaman. Di tempat baru, penduduk migran akan menghadapi saat-saat yang sulit, seperti tidak dapat berkomunikasi dengan masyarakat sekitar, perbedaan kultur dan budaya hingga agama dan kepercayaan. Tetapi penduduk migran mengambil peluang ini dan berharap akan berhasil di tempat perantauan. Faktor pendorong masyarakat memilih tempat untuk menetap saat migrasi adalah harapan ekonomi yang lebih baik, alasan kemanan dilihat dari konflik yang terjadi dalam masyarakat, terakhir adalah peluang kerja yang tersedia di tempat perantauan (Rahmawati, 2018). 
Sehingga kelompok masyarakat yang memasuki daerah baru akan melakukan adaptasi terhadap lingkungan sosial budaya dan fisik (Cohen, 1992).

Penduduk migran agar tetap bertahan hidup di tempat baru, lazimnya mereka akan melakukan adaptasi dengan lingkungan sosial budaya setempat dan masyarakat setempat. Penduduk migran berusaha untuk menyesuaikan diri dengan lingkungan baru karena didorong untuk memenuhi kebutuhannya. Strategi adaptasi di lingkungan mayarakat tujuan mulai dari pemilihan pemukiman sampai jenis pekerjaan. Penduduk migran harus bisa menyesuaikan diri dengan lingkungan baru, baik itu lingkungan sosial budaya maupun fisiknya. Sehingga dibutuhkan kecermatan dalam memahami pola adaptasi kelompok penduduk migran di tengah masyarakat lokal agar tidak terjadi konflik antar kepentingan (Nasution, 2018). Sementara itu, Masyarakat lokal tuan rumah (host population) mempertahankan budayanya dari pengaruh kebudayaan luar khususnya yang bersifat negatif.

Sehingga perlu dilakukan pola dan strategi adaptasi yang dilakukan penduduk migran terhadap lingkungan sosial baru. Pola adaptasi yang dilakukan penduduk migran adalah menyesuaikan diri dan fleksibilitas di dalam lingkungan masyarakat, sehingga dapat menuju ke arah keseimbangan. Arah keseimbangan yang diharapkan ini menjadi suatu tujuan agar konflik dalam masyarakat dapat ditekan . Adaptasi yang dilakukan masyarakat migran dengan membuka diri untuk menerima perbedaan budaya yang ada, berfikir luas tentang perbedaan (open minded) dan bergabung dengan kegiatan-kegitan di masyarakat (Sundayani et al, 2018; Pangestu, 2018; Indira et al, 2019).

Selain itu, beberapa strategi adaptasi yang dilakukan masyarakat migran di tempat perantauan adalah adaptasi terhadap bahasa yang digunakan masyarakat sekitar. Adaptasi sosial, misal mengikuti acara pernikahan dan acara kemasyarakatan lainnya. Kemudian melakukan perkawinan antara penduduk lokal dan masyarakat migram. Terakhir adalah adaptasi makanan-makanan khas masyarakat lokal (Robi, 2019; Rahmawati, 2018). Namun, proses adaptasi sosial menimbulkan beberapa dampak negatif yang ditimbulkan. Perbedaan perlakuan yang dilakukan pemerintah 
terhadap masyarakat migran dan penduduk lokal sering menimbulkan gesekan (Iqbal, 2018).

Desa Fusha merupakan salah satu desa yang berada di Kecamatan Wano Kabupaten Pamekasan. Mayoritas masyarakat lokal berpenghasilan dari kegiatan pertanian, buruh tani, berdagang, dan sektor jasa. Sedangkan penduduk migran lebih banyak bekerja di birokrasi pemerintahan, pedagang khususnya makanan dan jasa. Berdasarkan profil desa (2019) terdapat beberapa penduduk pendatang (migran) khususnya dari Jawa yang menetap di Desa Fusha. Lamanya bertempat tinggal penduduk migran di Desa Fusha bermacam-macam, ada yang sudah lima tahun, dua puluh tahun bahkan ada yang sudah lebih dari tiga puluh tahun.

Penelitian ini bertujuan menganalisis faktor apa saja yang membuat penduduk migran tertarik tinggal di Desa Fusha Kecamatan Wano Kabupaten Pamekasan, kemudian bagaimana strategi proses adaptasi sosial budaya penduduk migran di lokasi tersebut. Artikel ini diharapkan menjadi panduan serta rujukan kepada penduduk migran atau penduduk lokal dalam menciptakan harmonisasi dalam masyarakat. Sehingga implementasi tentang kerukunan dalam masyarakat dapat terlaksana. Upaya menemukan hambatan-hambatan yang dialami oleh penduduk migran yang berasal dari luar Madura terkait proses adaptasi mereka dengan nilai-nilai sosial budaya penduduk asli di Desa Fusha dan strategi untuk mengatasi hal tersebut. Akhirnya, berbagai konflik yang ditimbulkan akibat benturan berbagai kepentingan antara penduduk migran dan penduduk lokal dapat diminimalkan.

\section{METODE PENELITIAN}

Pendekatan studi kasus dalam Penelitian kualitatif ini terdisi dari kasus yang terjadi pada masyarakat migran di Desa migram. Menganalisis yang menjelaskan fenomena sosial kondisi masyarakat saat ini, situasi yang berlangsung dalam hubungan sosial yang diciptakan oleh masyarakat migran. Gambaran menyeluruh, komprehensif dan mendalam mengenai fenomena rasionalitas masyarakat migran memilih Desa Fusha sebagai tempat tinggal, kemudian proses sosial dan strategi adaptasi yang dilakukan di dalam masyarakat. Penelitian ini dilakukan terhadap masyarakat migran 
dengan ketentuan Informan merupakan penduduk migran yang tinggal di Desa Fusha yang sudah menetap lebih dari 10 tahun. Tokoh masyarakat digali informasi seputar adaptasi sosial yang dilakukan saat pertama sampai di Desa Fusha. Sedangkan aparatur desa digali data seputar pengurusan berkas dan status masyarakat migran yang sudah menetap di Desa Fusha. Sementara itu, penduduk lokal atau masyarakat migran yang baru dating dan menetap tidak lebih dari satu tahun berperan sebagai informan pendukung (Creswell; 2009).

Data dikumpulkan dari wawancara dengan penduduk migran, observasi dan catatan lapangan tentang rasionalitas dan adaptasi sosial masyarakat migran di Desa Fusha. Ada sebagian data yang diperoleh dari dokumen-dokumen pendukung yang tidak diperoleh secara langsung saat di lapangan seperti arsip yang tersimpan di balai desa. Pengujian validitas dan dan reabilitas digunakan menghasilkan kepercayaan (Miles dkk, 2014). Sementara itu, Data yang diperoleh, kemudian diolah dan dianalisis menggunakan model analisis data interaktif Miles dan Huberman (2014) Aktivitas dalam analisis meliputi reduksi data (data reduction), penyajian data (data display) serta Penarikan kesimpulan dan verifikasi (conclusion drawing/ verification). Setelah data dianalisis, kemudian dilakukan keabsahan data menggunakan dengan ketekukan observasi, pemeriksaan sejawat, triangulasi; 1) sumber, dan 2) metode untuk meminimalkan terjadi kesalahan dan tumpang tindih hasil penelitian. Sehingga menghasilkan laporan penelitian yang kredibel.

\section{HASIL DAN PEMBAHASAN}

\section{Hasil}

Saat penentuan lokasi tempat tinggal, masyarakat migran melakukan pertimbangan tersendiri. Masyarakat migran memilih Desa Fusha karena masih terbukanya lowongan pekerjaan untuk membuka usaha. Menurut masyarakat migran, sebagian besar penduduk lokal di Desa Fusha bekerja di bidang pertanian, yaitu petani atau buruh tani. Selain bergerak di bidang pertanian, masyarakat juga bekerja sebagai pedagang, baik itu sebagai pedagang di pasar, aneka jenis makanan dan pedagang kelontong. Ada 
beberapa penduduk yang bekerja sebagai guru sekolah, pengrajin, buruh bangunan, dan penjahit. Untuk memenuhi kebutuhan mereka sehari-hari, masyarakat juga mendapatkan hasil dari peternakan. Masyarakat memiliki hewan ternak seperti sapi, kambing, kuda, bebek, ayam sebagai mata pencaharian sampingan. Ternak ini menjadi dana cadangan bila sewaktuwaktu mata pencaharian utama tidak menghasilkan. Sedangkan penduduk migran di Desa Fusha bekerja sebagai Pegawai Negeri Sipil (PNS), wiraswasta dan bergerak di bidang jasa.

Penduduk migran dalam memilih lokasi lazimnya ditentukan oleh beberapa faktor. Faktor yang paling dominan adalah tersedia lapangan kerja, dekat dengan pusat kota dan mobilisasi penduduk yang tinggi. Mobilisasi penduduk yang tinggi dimanfatkan oleh masyarakat migran untuk membuka usaha makanan dan berbagai jenis jasa. Beberapa literatur menjelaskan beberapa alasan yang membuat penduduk migran memilih lokasi tempat untuk tinggal. seperti dari penjelasan Bapak Garp dalam memilih Desa Fusha sebagai tempat tinggal;

"saya memilih desa ini karena suasana masyarakat yang rukum, kompak ketika ada acara. Untuk fasilitas kesehatan, pendidikan sudah cukup lengkap meskipun tidak selengkap di pusat kota. Tapi lingkungan yang nyaman membuat saya betah dan cocok di Desa Fusha ini. Meskipun agak jauh dari pusat kota" (Wawancara: 2019).

Penduduk migran memilih Desa Fusha karena lingkungan masyarakat yang lebih menerima keberagaman, tersedianya fasilitas kesehatan, pendidikan, perekonomian (pasar) sehingga meskipun jarak ke pusat kota jauh penduduk lebih memilih Desa Fusha dari pada daerah di pinggiran kota. Faktor lain yang menjadi pemilihan Desa Fusha oleh penduduk migran yang berasal dari luar Madura yaitu faktor sosial kemasyarakatan, agama atau kepercayaan, ekonomi, pendidikan, keluarga, maupun tuntutan pekerjaan. Pada umumnya masyarakat migran di Desa Fusha yang berasal dari luar Madura berprofesi sebagai pedagang dan pegawai.

Di Desa Fusha terdapat fakta selain masyarakat lokal suka merantau ke luar Madura, banyak penduduk yang berasal dari luar Madura yang melakukan migrasi ke Desa Fusha. Hal itu tidak bisa dipungkiri karena sebagian dari mereka ada yang sudah lama menetap di Desa Fusha. 
Penduduk migran yang berada di Desa Fusha berasal dari berbagai daerah, seperti Malang, Solo, Gresik, Lamongan, Yogyakarta, Rembang, dan Mojokerto. Tapi yang paling banyak terdapat di Desa Fusha adalah penduduk migran yang berasal dari Malang.

Setelah menentukan lokasi tempat tinggal, masyarakat migran melakukan adaptasi sosial di lingkungan tersebut. Salah satu contoh adalah dalam bidang pekerjaan. Pekerjaan penduduk lokal dan penduduk migran membuat pola kehidupan sosial yang erat satu sama lain. Hal ini disebabkan karena sebagian besar masyarakat saling berdampingan dalam pemenuhan kebutuhan ekonomi, pertanian maupun perdagangan. Walaupun latar belakang penduduk di Desa Fusha berbeda dengan penduduk migran yang berasal dari luar Madura, interaksi sosial dalam masyarakat tidak pernah menimbulkan konflik suku atau agama. Pembauran masyarakat yang terjadi di Desa Fusha tidak dapat dibedakan lagi dari kesukuan baik Suku Madura sebagai warga lokal ataupun Suku Jawa sebagai penduduk migran. Bahkan orang-orang yang ada di desa ini, terutama penduduk migran yang berasal dari luar Madura, ada beberapa yang sudah mahir dalam menggunakan bahasa Madura dan sebaliknya. Hubungan erat satu sama lain dalam masyarakat juga berjalan dalam organisasi setempat. Organisasi yang ada di Desa Fusha berjalan dengan optimal walaupun masyarakat dari latar belakang suku yang berbeda-beda, khususnya suku Jawa sebagai pendatang dan suku Madura sebagai masyarakat lokal. Beberapa kegiatan warga di Desa Fusha antara lain; bakti sosial seperti membantu warga yang kurang mampu, biasanya dilakukan bersama dengan kegiatan keagamaan. Selain itu kontribusi masyarakat untuk pembangunan masjid atau musholla, kerja bakti, pengajian rutin, dan arisan warga.

Selain faktor pekerjaan, kegiatan ekonomi, dan organisasi masyarakat setempat, kehidupan sosial masyarakat di Desa Fusha sangat erat, hal ini dapat dilihat dari kegiatan sosial, budaya dan agama. Masyarakat dapat hidup berdampingan dan bekerjasama dalam setiap kegiatan. Misal contoh; saat ada kegiatan upacara perkawinan salah seorang anggota masyarakat di Desa Fusha. Dalam acara tersebut semua lapisan masyarakat di Desa Fusha berkumpul saling membantu, tidak terkecuali penduduk migran yang berasal dari luar Madura agar tetap terciptanya kebersamaan. Kemampuan 
membantu disesuaikan dengan kemampuan masing-masing individu. Misal Wulan memiliki mobil Pick-up, ini digunakan sebagai angkutan saat membeli berbagai kebutuhan untuk acara tersebut.

Strategi adaptasi sosial digunakan oleh penduduk migran di Desa Fusha untuk mengatasi hambatan yang mereka hadapi guna memperoleh keseimbangan yang positif dengan masyarakat lokal. Adaptasi sosial yang dilakukan oleh masyarakat migran di Desa Fusha, pertama; adaptasi bahasa, karena sebagian besar penduduk migran berasal dari Jawa. Strategi adaptasi terhadap bahasa Madura dilakukan penduduk migran karena mengalami kesulitan dalam berkomunikasi dengan masyarakat lokal. Awalnya penduduk migran belum sepenuhnya memakai bahasa Madura saat berkomunikasi dengan masyarakat lokal. Mereka masih mempertahankan bahasa mereka masing-masing dan terkadang menggunakan bahasa Indonesia. Tetapi seiring berjalannya waktu, dalam berkomunikasi penduduk migran sudah mulai belajar menggunakan bahasa Madura. Komunikasi menggunakan bahasa Madura terjadi bukan karena adanya dominasi kaum mayoritas adalah penduduk lokal kepada kaum minoritas yaitu masyarakat migran. Namun lebih kepada penyesuain dan kebiasaan yang terjadi dalam proses adaptasi sosial.

Saat ada kegiatan resmi atau sekedar berkumpul antar tetangga sesekali komunikasi menggunakan bahasa Indonesia oleh penduduk migran, tetapi penggunaan bahasa Indonesia yang jarang digunakan oleh masyarakat lokal menjadi tidak efektif. Penduduk migran mulai mengikuti percakapan yang didengar sehari-hari, sehingga lama-kalamaan menjadi mahir berbahasa Madura. Keakraban tersebut terjadi karena pemukiman masyarakat yang saling berdekatan. Sehingga menimbulkan hubungan yang erat antara anggota masyarakat yang satu dengan masyarakat yang lain. Seperti penjelasan Bapak Aokiji, ketika Bapak Garp menggunakan bahasa Madura dengan gaya pengucapan atau logat Jawa menjadi candaan tersendiri. Hal ini menambah keakraban antara masyarakat lokal dan penduduk migran di Desa Fusha. Pada umumnya dalam proses adaptasi sosial seseorang individu yang memasuki lingkungan sosial baru dengan sendirinya akan menyesuaikan diri. Hal ini dilakukan agar setiap individu 
atau kelompok dapat diterima oleh masyarakat yang dimasukinya. Adaptasi ini perlu agar manusia itu dapat bertahan lama di lingkungan yang baru.

Kedua, adaptasi sosial kultural. Penduduk migran mengikuti berbagai kegiatan warga seperti tahlilan, pernikahan dan beberapa kegiatan lainnya. Masyarakat migran membantu kegiatan warga mulai dari perencanaan, persiapan sampai pelaksanaan. Terakhir adalah kegiatan warga sebagai pemenuhan kebutuhan integratif setiap individu dalam masyarakat (Setyaningrum et al, 2019).

Penduduk Desa Fusha mayoritas beragama Islam dan taat dalam menjalankan perintah agama. Hal ini terlihat dalam kehidupan sehari-hari, misal; masyarakat lebih memilih sekolah Madrasah (MI, MTS, MA) dan pondok pesantren dari pada sekolah formal SD SMP dan SMA. Anak-anak dan remaja di Desa Fusha banyak yang pergi belajar ke pondok pesantren untuk mendalami ilmu agama. Selain itu, dalam setiap kegiatan atau hajatan yang dilakukan oleh masyarakat selalu diawali dan diakhiri secara keagamaan, seperti acara syukuran dengan memanggil kiai (memiliki kemampuan dalam ilmu agama) di Desa Fusha untuk mendo'akan agar mendapat hasil yang maksimal. Hal ini menempatkan kiai dalam masyarakat Madura sebagai rujukan utama dalam berbagai bidang kehidupan seperti ekonomi, kesehatan dan lainnnya (Wiyata, 2004). Hal ini senada dengan penjelasan tentang peran kiai dalam masyarakat tradional. Kiai sebagai tokoh sentral di dalam masyarakat tradisional berfungsi sebagai otoritas tertinggi yang selalu dipatuhi oleh penganut Islam tradisional. Kepatuhan masyarakat tradisional terhadap sosok Kiai menciptakan otoritas tertinggi dan berfungsi sebagai sistem control. Kiai sebagai otoritas tertinggi dalam masyarakat tradisional juga bisa dikatakan sebagai agen perubahan sosial dan perdamaian (Nasution, 2017). Penduduk migran melakukan pendekatan terhadap kiai dalam proses adaptasi sosial, meskipun secara sosial peran kiai di Jawa dan di Madura berbeda. Penduduk migran mengikuti adat istiadat masyarakat lokal dalam menempatkan kiai. Bagi masyarakat migran, kiai tidak sebatas kegiatan keagamaan tetapi juga dalam bidang ekonomi, kesehatan, mendoakan keselamatan sampai mencari jodoh.

Masyarakat Desa Fusha pada setiap hari besar agama Islam seperti: Maulid Nabi Muhammad SAW, Isra' Mi’raj, Idul Fitri, Idul Adha, Sya’ban 
selalu mengadakan perayaan. Pelaksanaan kegiatan ritual keagamaan ini lazimnya ditempatkan di masjid dan musholla yang ada di Desa Fusha. Penduduk migran mengikuti berbagai kegiatan tersebut misal seperti perayaan Maulid Nabi Muhammad SAW. Menurut Bapak Garp di Jawa perayaan tersebut hanya dilakukan di Masjid-masjid dan musholla. Tetapi di Desa Fusha hampir setiap warga lokal merayakannya di rumah masingmasing. Pelaksanaannya dengan mengundang tetangga dan warga sekitar, disesuaikan dengan kemampuan tuan rumah untuk bersedekah makanan yang dihidangkan dan ada yang berupa sembako. Penduduk migran mengikuti adat istiadat yang telah berkembang dalam masyarakat. Hal ini diaplikasikan oleh beberapa penduduk migran dalam menyesuaikan diri dengan lingkungan sosial baru.

Ketiga; adaptasi makanan. Adaptasi ini disesuaikan dengan selera masyarakat lokal misal masyarakat lokal tidak terlalu suka masakan manis (kebanyakan masakan penduduk migran suka dengan masakan manis dan pedas) sedangkan penduduk lokal lebih suka rasa asin pedas. Penduduk migran terbiasa dengan masakan manis dan pedas, maka menyesuaikan dengan masakan khas Madura yang cenderung asin atau tidak suka masakan yang terlalu manis dan terlalu pedas. Misal Pak Doni sebagai penduduk pendatang dari Jawa akan mengadakan pesta pernikahan anaknya. Pak Doni berdiskusi dengan tokoh masyarakat Desa Fusha untuk meminta salah satu perempuan yang memiliki kemampuan memasak. Sehingga nanti aneka makanan yang disajikan sesuai dengan selera masyarakat di Desa Fusha.

Selain itu, strategi adaptasi terhadap makanan dilakukan karena sebagian besar penduduk migran di Desa Fusha berprofesi sebagai pedagang makanan. Makanan olahan seperti mpek-mpek, bakso, mie ayam, nasi goring dan beberapa makanan ringan seperti Gorengan, Cilok, Sempol. Penyediaan makanan yang dijual oleh penduduk migran yang berasal dari luar Madura khususnya Jawa menyesuaikan dengan pola makanan khas Madura. Strategi adaptasi terhadap makanan Madura juga penting dilakukan oleh penduduk migran yang berasal dari luar Madura. Hal ini dikarenakan sebagian besar dari penduduk migran yang berasal dari luar Madura berprofesi sebagai pedagang. Menurut penduduk migran khususnya yang 
berprofesi sebagai penjual makanan, strategi adaptasi tersebut harus dilakukan untuk keberlangsungan kegiatan usaha dagangannya.

Keempat; melakukan pernikahan silang antara penduduk migran dan masyarakat lokal. Penduduk migran menikahkan salah satu anaknya dengan masyarakat lokal. Seperti yang dijelaskan oleh Bapak Garp dengan pernikahan tersebut akan menciptakan nilai-nilai kebersamaan yang tinggi. Misal saat kedua keluarga melakukan diskusi tentang proses lamaran, acara akad nikah, prosesi resepsi hingga pasca pernikahan. Proses diskusi ini memimbulkan keterbukaan antar masing-masing adat istiadat baik adat Jawa dan adat Madura untuk mencapai suatu kesepakatan. Sehingga proses adaptasi sosial penduduk migran di Desa Fusha menjadi lebih cepat.

\section{Pembahasan}

Pilihan penduduk migran dalam memilih desa Fusha sebagai tempat tinggal jika dikaitkan dengan teori tindakan rasionalitas Weber (Turner, 2012) mengungkapkan individu melakukan sesuatu tindakan dan memutuskan untuk mencapai apa yang mereka kehendaki. Setelah memilih sasaran, mereka memperhitungkan keadaan, kemudian memilih tindakan yang tepat. Bagi Weber, struktur sosial adalah produk (hasil) dari tindakan itu, cara hidup adalah produk dari pilihan yang dimotivasi. Memahami realitas sosial yang dihasilkan oleh tindakan itu berarti menjelaskan mengapa manusia menentukan pilihan (Turner, 2012 Ritzer, 2012). Rasionalitas dijelaskan dari motivasi yang dipilih oleh masyarakat migran. Tempat tinggal tersebut dipilih berdasarkan pada rasional tiap individu.

Selain memusatkan perhatian pada tindakan yang berorientasi tujuan dan motivasi pelaku, Weber juga yakin bahwa cara terbaik untuk memahami berbagai masyarakat adalah menghargai bentuk-bentuk tipikal tindakan yang menjadi ciri khasnya dengan merekonstruksi makna. Menurut Weber, kita bisa membandingkan struktur beberapa masyarakat dengan memahami alasan-alasan mengapa masyarakat bertindak, kejadian-kejadian historis secara berurutan yang mempengaruhi karakter mereka dan memahami tindakan pada pelakunya yang hidup di masa kini, akan tetapi walaupun demikian kita tidak bisa menggeneralisasi semua masyarakat atau semua struktur sosial (Turner, 2012). Rasionalitas mengacu pada 
perhitungan yang masuk akal untuk mencapai sasaran berdasarkan pilihanpilihan dan perangkat kerja yang efisien. Dari empat rasionalitas yang ditawarkan Weber, fenomena pemilihan tempat tinggal bagi penduduk migran di Desa Fusha adalah Rasionalitas praktis. Tindakan sosial dalam rasionalitas ini diarahkan pada tujuan yang ditentukan oleh harapan terhadap perilaku objek dalam menentukan pilihan rasionalitas. Untuk sampai ke tujuan, tindakan yang diambil seefisien mungkin dengan cara yang terbaik.

Jika dikaitkan dengan teori pilihan rasional yang dijelaskan Coleman (Ritzer, 2018). Coleman menjelaskan jika pilihan atau tindakan seseorang dilatar belakangi dan dibentuk oleh nilai-nilai atau pilihan-pilihan. Para aktor disini adalah penduduk migran di Desa Fusha melakukan tindakan dalam rangka mengoptimalkan manfaat berbagai keuntungan dan kebutuhan dari sumber daya yang ada. Sumber daya yang ada dijelaskan dengan pemilihan lokasi Desa Fusha menjadi suatu pilihan yang dijelaskan secara rasional oleh penduduk migran. Sehingga penduduk migran memilih Desa Fusha karena lingkungan masyarakat yang lebih menerima keberagaman, tersedianya fasilitas kesehatan, pendidikan, perekonomian (pasar) sehingga meskipun jarak ke pusat kota jauh penduduk lebih memilih Desa Fusha dari pada daerah di pinggiran kota. Terdapat rasionalitas-rasionalitas tersendiri dari masing-masing individu yang dapat diterima dan diikuti oleh kelompok masyarakat. Pada kasus ini adalah masyarakat migran saat memilih tempat tinggal (Moanisa et al, 2013; Rahmawati, 2018).

Tidak hanya rasionalitas dalam memilih tempat tinggal, adaptasi sosial dilakukan masyarakat migran di tempat lingkungan baru. Adaptasi sosial merupakan strategi menyesuaikan diri dengan lingkungan sosial (Setyaningrum et al, 2019: 90). Beberapa strategi yang dilakukan adalah dengan menggunakan Bahasa lokal (Malik, 2016; Robi, 2019). Komunikasi dengan menggunkan Bahasa lokal disesuaikan dengan kondisi masyarakat yang dihadapi. Sehingga perpaduan ini memudahkan dalam komunikasi dalam masyarakat ketika terjadi perbedaan bahasa (Robi 2019, Rahmawati, 2018).

Selain Bahasa, kegiatan adaptasi kultural yang dilakukan oleh masyarakat migran tersebut merupakan sebuah pemenuhan kebutuhan integratif setiap individu dalam lingkungan sosial (Setyaningrum et al, 
2019). Pemenuhan kebutuhan integrative ini menciptakan suatu kohesitas sosial antara masyarakat migran dan penduduk lokal. Strategi adaptasi pola komunikasi melalui Bahasa lokal, adaptasi sosial kultur, adaptasi terhadap pola makanan dan pernikahan antara penduduk migran dan masyarakat lokal menurut Weber (Turner, 2012) adalah tindakan rasional berorientasi nilai. Tindakan yang dilakukan penduduk migran, baik yang bekerja sebagai pedagang makanan atau masyarakat yang tidak berdagang bersifat rasional dan memperhitungkan manfaatnya, tetapi tujuan yang hendak dicapai tidak terlalu dipentingkan oleh si pelaku itu sendiri yaitu penduduk migran. Penduduk migran beranggapan bahwa yang paling penting tindakan itu termasuk dalam kriteria baik dan benar menurut ukuran dan penilaian masyarakat di sekitarnya. Sama halnya dengan penduduk migran yang tinggal di Desa Fusha mereka melakukan pelbagai usaha untuk menyesuaikan kondisi sosial yang sudah ada dalam masyarakat. Sehingga relasi sosial mengarah pada pertukaran sosial (Hidayat et al, 2016).

\section{KESIMPULAN}

Rasionalitas dalam memilih lokasi tempat tinggal bagi masyarakat migran sangat penting. Hal ini berkaitan dengan langkah yang akan dilakukan ke depan, karena sebagian besar masyaakat migran di Desa Fusha bekerja sebagai wirausaha. Studi ini mengungkap bahwa rasionalitas penduduk migran memilih Desa Fusha karena lingkungan masyarakat yang lebih menerima keberagaman, tersedianya fasilitas kesehatan, pendidikan, perekonomian (pasar) sehingga meskipun jarak ke pusat kota jauh penduduk lebih memilih desa ini dari pada daerah di pinggiran kota. Sedangkan adaptasi sosial yang dilakukan oleh masyarakat migran di Desa Fusha, pertama; adaptasi bahasa. Kedua, adaptasi sosial kultural, penduduk migran mengikuti berbagai kegiatan warga seperti tahlilan, pernikahan dan beberapa kegiatan lainnya. Ketiga; adaptasi makanan disesuaikan dengan selera masyarakat lokal misal masyarakat lokal tidak terlalu suka masakan manis (kebanyakan masakan penduduk migran suka dengan masakan manis) sedangkan penduduk lokal lebih suka rasa asin pedas. Strategi adaptasi terhadap makanan Madura juga penting dilakukan oleh penduduk 
migran yang berasal dari luar Madura. Hal ini dikarenakan sebagian besar dari penduduk migran yang berasal dari luar Madura berprofesi sebagai pedagang. Mereka menjual berbagai makanan dan minuman. Jadi menurut penduduk migran yang berprofesi sebagai penjual makanan, strategi tersebut memang harus dilakukan. Keempat; melakukan pernikahan silang antara penduduk migran dan masyarakat lokal.

Kajian ini dapat dijadikan acuan oleh penduduk migran, bahwa dalam bermigrasi di tempat yang baru membutuhkan strategi adaptasi dengan lingkungan yang baru tersebut agar dapat diterima oleh masyarakat setempat. Adaptasi yang dilakukan memang sangat sulit jika berbeda kebudayaan. Tetapi dengan mengikuti dan mempelajari sosial kultur masyarakat lokal akan terjadi proses sosial yang baik dalam masyarakat. Begitu juga dengan masyarakat lokal dalam menerima penduduk migran. Masyarakat migran lebih membuka diri jika dinilai mampu memberikan kemajuan dalam bidang ekonomi, pendidikan dan kesehatan.

\section{DAFTAR PUSTAKA}

Creswell, John W. 2009. Reasearch Design Qualitative, Quantitative, and Mixed Methods Approaches Third Edition. Singapura: SAGE Publications,inc.

Cohen, Bruce J. 1992. Sosiologi suatu Pengantar. Jakarta: PT. Rineka Cipta.

Hidayat, F. K., Pratiwi, P. H. 2016. Pola Interaksi dan Prilaku Pertukaran Kelompok Nelayan TPI Udang Jaya Desa Keburuhan Kecamatan Ngombol Purwerejo. Jurnal Analisa Sosiologi, 5 (1): 32-43.

Indira, Dian. Raden Muhammad Mulyadi, Riki Nasrullah. 2019. Komunitas Jawa di Desa Wonoharjo Sebagai Jejak Migrasi Etnis Jawa ke Kabupaten Pangandaran. Sosiohumaniora-Jurnal Ilmu-ilmu Sosial dan Humaniora, 21(1): 34-39.

Iqbal, Muhammad. 2018. Integrasi dan Adaptasi Sosial Migrant di Korea Selatan. Jurnal Ilmu Kesejahteraan Sosial, 19 (1): 23-34.

Malik, Rahman. 2016. Ikatan Kekerabatan Etnis Minangkabau dalam Melestarikan Nilai Budaya Minangkabau di Perantauan Sebagai 
Wujud Negara Kesatuan Republik Indonesia. Jurnal Analisa Sosiologi, 5 (1) :43-54.

Miles,M.B, Huberman,A.M, dan Saldana,J. 2014. Qualitative Data Analysis, A Methods Sourcebook, Edition 3. USA: Sage Publications. Terjemahan Tjetjep Rohindi Rohidi, UI-Press.

Moanisa, Moanisa. Bambang Bemby Soebyakto, Lili Erina. 2013. Analisis Alasan Migrasi Masuk di Kota Muaradua Kabupaten Oku Selatan Setelah Pemekaran Wilayah. Demography Journal of Sriwijaya (DeJoS), 1 (1): 37-50.

Nasution, Robby Darwis. 2017. Kyai Sebagai Agen Perubahan Sosial dan Perdamaian dalam Masyarakat Tradisional. Jurnal Sosiohumaniora, 19 (2):177-184.

Nasution, Sri Ilham. 2018. Pola Adaptasi dalam Hubungan Antar Etnik di Kota Bandar Lampung. E-jurnal Komunika Raden Intan, 1 (2): 149173.

Pangestu, Mutiara Gayatri. 2018. Bentuk Culture Shock dan Strategi Adaptasi Orang Jepang (Studi Kasus Lima Orang Jepang yang bekerja di Cikarang Selatan). thesis, President University Repository. Diakses dari Repository .President.ac.id/12349/578

Profil Desa Fusha Kecamatan Wano Kabupaten Pamekasan (2019).

Rahmawati, Ela. 2018. Adaptasi Sosial Budaya Suku Sunda di Desa Polo Lereng Kecamatan Pangale Kabupaten Mamuju Tengah Provinsi Sulawesi Barat. thesis, Universitas Negeri Makassar. Diakses dari eprints.UNM.ac.id/10477/

Ritzer, George. 2012. Teori Sosiologi. Yogyakarta: Pustaka Belajar.

Robi, Mitra. 2019. Adaptasi Sosial Budaya Etnis Nias di Minangkabau (Studi Kasus Etnis Nias di Nagari Tiku V Jorong, Kecamatan Tanjung Mutiara, Kab. Agam). thesis, Universitas Negeri Makassar. Diakses dari Scholar.unand.ac.id/47854/

Setyaningrum, Gus Miyana Nela. Agus Cahyono. 2019. Strategi Adaptasi Masyarakat Non Hindu pada Pertunjukan Ogah-Ogah di Desa Linggoasri Kecamatan Kajen Kabupaten Pekalongan. Jurnal Seni Tari, 8 (1): 83-94. 
Sundayani, Yana. Adi Fahrudin, Binahayati R. Nunung Nurwati. 2018. Adaptasi Anak Pekerja Migran di Kabupaten Cianjur Indonesia. Asian Social Work Journal, 3 (5): 9-17.

Turner, Bryan S. 2012. Teori Sosial dari Klasik sampai Postmodern. Yogyakarta: Pustaka Belajar.

Wiyata, A. Latief. 2006. Carok Konflik Kekerasan dan Harga Diri Orang Madura, Cetk. Kedua. Yogyakarta: LKiS.

Wawancara

Bapak Aokiji (60 tahun), tokoh masyarakat lokal. Tanggal 14 November 2019.

Bapak Garp (53 tahun), penduduk Migran di Desa Fusha. Tanggal 13 November 2019.

Wawancara dengan aparatur Desa Fusha pada Agustus 2019. 